may have contributed to management fail-

\title{
Rogers Commission report makes waves all round
}

Washington

DESIGN flaws, organizational problems and inadequate safety procedures all played a role in the accident on 28 January that destroyed the space shuttle Challenger, according to the presidential commission chaired by William P. Rogers, whose 250-page report was published this week.

The commission concludes that the accident to mission $51 \mathrm{~L}$ occurred when a gas leak developed at the joint connecting two segments of the right solid rocket booster (SRB). The leak developed within seconds of launch, showing up in photographs as a puff of black smoke. Then it evidently sealed itself, possibly with combustion products from the booster, but after the shuttle successfully passed through severe wind shear, the leak reappeared 58 seconds after lift-off.

Then the slipstream directed the burning gas from the leak onto the external fuel tank, ultimately burning a hole in it. At 72 seconds, the lower strut holding the booster to the fuel tank was severed or pulled away, allowing the booster to pivot, smashing into the external fuel tank and releasing massive amounts of liquid hydrogen. Within milliseconds there was a "massive, almost explosive burning" of the hydrogen spilling from the tank.

The commission concluded that the accident occurred because $\mathrm{O}$-rings supposed to form a seal between two segments of the right solid rocket booster failed to do so. The O-ring seals are designed to be "pressure actuated", only sealing once increased pressure is applied to the joint by the firing of the rocket motor. The commission concluded that the failure was due to "a faulty design".

The commission was also critical of the process that resulted in the decision to launch Challenger. Testimony presented to the commission revealed that the decision to fly was based on "incomplete, and sometimes misleading information". The O-rings had been identified as early as December 1982 as parts whose failure could result in a mission disaster. In July 1985, SRB manager Lawrence Mulloy placed a launch constraint on all shuttle launches, which meant that a waiver had to be signed before each flight could proceed. But neither the constraint nor the waivers were known to the director of the shuttle programme or his senior deputies.

The 24 previous successful launches of the shuttle also contributed to the accident. As commission member Richard Feynman put it, NASA convinced itself that safety standards could be lowered a little bit after each launch "because we got away with it last time".

The commission also investigated the pressures on the shuttle programme caused by NASA's reluctance to relax optimistic schedules. A critical shortage in spare parts forced NASA to turn to cannibalization, borrowing parts from one

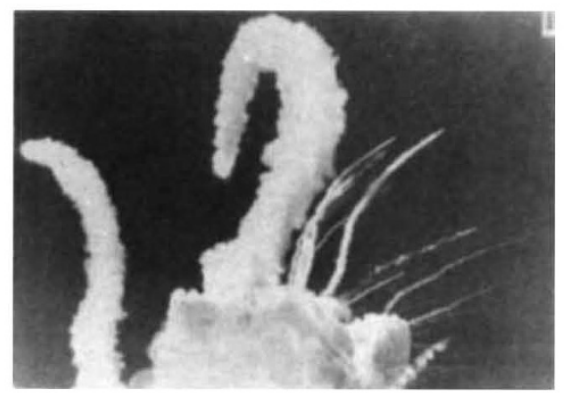

orbiter to allow another one to fly. But the accelerated launch schedule meant the shuttle would either be in orbit or preparing for launch, thus not available for supplying spare parts.

The commission's chief recommendation is that the faulty joint and seal of the solid rocket booster should be either eliminated or redesigned. But other recommendations are likely further to increase the cost of bringing the shuttle back into service and to decrease the rate of shuttle launches thereafter.

The booster joints had for several years been suspect. Instead of a complete redesign of the joint, now as seen as necessary, Morton Thiokol Inc. and NASA opted for some retesting and the imposition of "launch constraints", which were then overridden for every launch after 10 July 1985.

The commission is forthright on the need for other safety improvements, landing safety included. Tyres on the landing gear are acknowledged by NASA to be "critical" components, but tyres have shown "excessive" wear during several previous landings. The brakes, which have been damaged on most flights, have "little or no margin".

The commission urges efforts to provide a crew escape system for use during gliding flight. Although early test flights of the shuttle included ejection seats, recent space missions have had no such feature, which would require a major effort, and probably taking up valuable space and weight. "Rocket-assisted extraction" is a possibility.

The commission, impressed that pressure on NASA to maximize launch rates ures and the accident, says the capabilities of the system stretched "to the limit" to support flight rate in winter 1985-86. In what may be one of the most significant long-term recommendations, the commission urges that the United States should not rely exclusively on the shuttle for launching capacity, a complete reversal of the administration's declared policy.

On management, Rogers says there must be a redefinition of the programme manager's responsibility. Project managers apparently felt more accountable to their particular NASA centre than to the programme as a whole.

Tim Beardsley \& Joseph Palca

\section{Other avenues?}

\section{Washington}

THE Rogers inquiry subdued the natural inclination of Congress to get involved; now that the report is public, both houses of Congress intend to hold hearings on the findings, and on the accident itself.

At least one senator, unable to wait until publication day on Monday, introduced legislation last week following a "recommendation by the Rogers Commission" to revive quality assurance at NASA. Congress has also been impatient with the inability of the White House to decide on buying a new orbiter, and may suggest its own plans for the agency.

The National Research Council (NRC) will also have a future role in the shuttle programme. NRC's standing review committee on NASA's scientific and technological programme will set up a panel to evaluate development and construction of the new solid rocket boosters.

NASA itself is also having to reevaluate its role. The Reagan administration no longer wants NASA to be the sole provider of launch services for commercial satellites, while the Department of Defense has already ordered ten Titan 34D7 rockets capable of launching payloads nearly as large as those carried by the shuttle.

Without the military or industry as steady users, will NASA find itself more interested in the needs of the scientific community? Bruce Murray, professor of planetary science at the California Institute of Technology and former director of the Jet Propulsion Laboratory, says NASA took a procrustean approach, forcing users to fit their projects to the shuttle's capabilities. Murray believes NASA will now have to serve space science and manned exploration of space.

For the time being, with no shuttle and no alternative launch vehicles, space science projects are dead in their tracks. Even if funds for scientific projects are preserved, NASA's chief scientist Frank McDonald says the shuttle's loss will damage the programme. Joseph Palca 